Scientific commentaries/Comentários científicos

\section{Neonatal jaundice and glucose-6-phosphate dehydrogenase}

Amauri Antiquera Leite

\begin{abstract}
Glucose-6-phosphate dehydrogenase in newborn babies may be responsible for neonatal jaundice. There is a concern of many authors from other countries in respect to complications in neonates with hyperbilirubinemia; some authors even propose screening for glucose-6-phosphate dehydrogenase deficiency in newborn babies. A scientific report on this subject is published in this issue.
\end{abstract}

Keywords: Glucosephosphate dehydrogenase deficiency; Jaundice, neonatal; Infant, newborn

The metabolism of the erythrocyte is very interesting because of the peculiarities of this cell with no nucleus. Its main function is to transport oxygen to tissues but without consuming it. Thermal energy is attained by the oxidation of glucose via the anaerobic pathway, which, although not very efficient or productive, is enough to meet its needs, especially to maintain the cell's biconcave shape. To obtain reducer energy, the red blood cell needs to divert $10 \%$ of the glucose consumed to the pentose phosphate cycle, with this being its only source of NADPH.

Through the pentose cycle, glucose-6-phosphate dehydrogenase (G6PD) and 6-phosphogluconate dehydrogenase (6PGD) enzymes reduce the nicotinamide adenine dinucleotide phosphate (NADP) coenzyme to its reduced form, NADPH, which is then used to maintain glutathione in its reduced state (GSH) by glutathione reductase. This pathway plays an important role in protecting red blood cells against the damage caused by oxidative stress, which is responsible for reducing the average life of erythrocytes. ${ }^{(1-3)}$

For G6PD-deficient erythrocytes, a drop in the reduction of NADP to NADPH leads to a low potential reducer. This interferes in the metabolic oxidation of the organism, making it vulnerable to hemolysis by failing to protect the sulfhydryl groups in hemoglobin from Heinz body formation. In turn oxidation of the red cell membrane may lead to varying intensities of hemolytic crises and neonatal jaundice after the ingestion of certain oxidizing drugs, and during infectious and oxidizing processes. ${ }^{(1,4)}$

The most serious consequence of G6PD deficiency is severe neonatal jaundice, which can lead to kernicterus. It is commonly believed that hyperbilirubinemia is a consequence of hemolysis, but in reality the level of hemoglobin and the reticulocyte count in infants are usually normal and, with the use of modern techniques, it has been shown that there is only a modest and inconsistent shortening of the life span of red blood cells which may, to a limited extent, contribute to jaundice. The main cause of neonatal jaundice in G6PD-deficient infants is the inability of the liver to conjugate bilirubin properly, thereby exacerbating the bilirubinemia. ${ }^{(5)}$

The study by Iglessias et al. ${ }^{(6)}$ presented in this issue shows that $3.0 \%$ of newborn males are G6PD deficient with one third of them suffering jaundice within 48 hours of life and bilirubin levels remaining higher than $10 \mathrm{mg} / \mathrm{dL}$. The most serious case occurred in a neonate with mild G6PD deficiency but with intense and prolonged bilirubin, suggesting that other factors are associated with hemolysis, as has previously been discussed. Other studies have also reported the frequency of G6PD deficiency ranging from 2 to $3 \%$ in the Brazilian population. ${ }^{(6-11)}$ Thus these data suggest that 6 million Brazilians have G6PD deficiency and that $1 \%$ of infants had episodes of jaundice to varying degrees associated to G6PD deficiency; 1.9 million Brazilians ran the risk of severe neonatal jaundice with a risk of kernicterus.

The latest unofficial report on kernicterus in the United States suggests that at least $21 \%$ of children with kernicterus have documented G6PD deficiency. ${ }^{(12)}$

These facts led Beutler ${ }^{(13)}$ to ask a series of reflective questions and proposals. Should all newborns be screened? Is the human and financial cost worth it? Should this screening be limited to ethnic groups that are known to have high frequencies of the gene and if so, how will they be identified? Or would it be better simply to monitor bilirubin levels in newborns more closely, thus sparing them the tragedy of kernicterus, whatever the cause?

\section{Resumo}

A deficiência de glicose-6-fosfato desidrogenase em neonatos pode ser a responsável pela icterícia neonatal. Este comentário científico é decorrente do relato sobre o tema publicado neste fascículo e que preocupa diversos autores de outros países em relação às complicações em neonatos de hiperbilirrubinemia, existindo inclusive proposições de alguns autores em incluir o teste para identificar a deficiencia de glicose-6-fosfato desidrogenase nos recém-nascidos.

Descritores: Deficiência de glucosefostato desidrogenase; Icterícia neonatal; Recém-nascido

\section{References}

1. Beutler E. Glucose-6-phosphate dehydrogenase deficiency and other red cell enzyme abnormalities. In: Beutler E, Lichtman MA, Coller BS, Kipps TJ, Seligsohn U. Williams Hematology. 6th ed. New York: McGraw-Hill; 2001. p. 527-39. 
2. Lukens JN. Deficiência de glicose-6-fosfato desidrogenase e deficiências relacionadas que envolvem a via da pentose fosfato e metabolismo da glutationa. In: Lee RG, Bithell TC, Foerster J, Athens JW, Lukens JN. Hematologia clínica de Wintrobe. São Paulo: Manole; 1998. p. 1101-13.

3. McMullin MF. The molecular basis of disorders of red cell enzymes. J Clin Path. 1999;52(4):241-44.

4. Ondei LS, Silveira LM, Leite AA, Souza DR, Pinhel MA, Percário $\mathrm{S}$, et al. Lipid peroxidation and antioxidant capacity of G6PDdeficient patients with A- $(202 \mathrm{G}>\mathrm{A})$ mutation. Gen Mol Res. 2009;8(4):1345-51.

5. Kaplan M, Hammerman C. Glucose-6-phosphate dehydrogenase deficiency: a hidden risk for kernicterus. Semin Perinatol. 2004; 28(5):356-64.

6. Iglessias MA, Santos RM, Amorin MS, Silva RT, Moreira SS, Barretto OC, Medeiros TM. Deficiência de glicose-6-fosfato desidrogenase eritrocitária em recém-nascidos do sexo masculino e sua relação com a icterícia neonatal. Rev Bras Hematol Hemoter. 2010;32(6):434-8.

7. Leite ER, Lessi JH, Mascarin DB, Leite AA. Pesquisa de deficientes em G6PD nos doadores de sangue da região de Araraquara. Bol Soc Bras Hematol Hemoter. 1996;18(Supl):337.

8. Katsuragawa TH, Soares Gil LH, Stábile RG, Pires MG, BoniniDomingos CR. Avaliação da incidência da deficiência de glicose-6fosfato desidrogenase (G6PD) e perfil hematológico em indivíduos de uma região de Rondônia. Rev Bras Hematol Hemoter. 2004; 26 (4):268-73

9. Castro S, Weber R, Dadalt V, Tavares V, Giugliani R. Prevalence of G6PD deficiency in newborns in the south of Brazil. J Med Screen. 2006;13(2):85-6

10. Compri MB, Saad ST, Ramalho AS. Investigação genético-epidemiológica e molecular da deficiência de G6PD em uma comunidade brasileira. Cad Saúde Pública [Internet]. 2000 [citado 2009 Jan 12];16(2):335-42. Disponível em: http://www.scielo.br/pdf/csp/ v16n2/2083.pdf

11. Nicolielo DB, Ferreira RI, Leite AA. Atividade da 6-fosfogliconato desidrogenase em deficientes de glicose-6-fosfato desidrogenase. Rev Bras Hematol Hemoter [Internet]. 2006 [citado 2009 Dez 21];28(2):135-8. Disponível em: http://www.scielo.br/pdf/rbhh/ v28n2/v28n2a14.pdf

12. Johnson LH, Bhutani VK, Brown AK. System-based approach to management of neonatal jaundice and prevention of kernicterus. J Pediatr. 2002;140(4):396-403. Comment in: J Pediatr. 2003; 142 (2):212-3; author reply 214-5. J Pediatr. 2002;141(4):597. J Pediatr. 2002;140(4):385-6. J Pediatr. 2003;142(2):213-4.

13. Beutler E. Glucose-6-phosphate dehydrogenase deficiency: a historical perspective. Blood. 2008;111(1):16-24

Submitted: 6/18/2010

Accepted: 7/8/2010

Clinical Analysis Department, Faculdade de Ciências

Farmacêuticas - UNESP, Araraquara (SP), Brazil

Correspondence: Amauri Antiquera Leite

Rua Padre Duarte, 989 - Centro

14801-310 - Araraquara (SP), Brasil

E-mail: leite.amauri@gmail.com

\section{Analysis of fatty acids in human plasma}

Jeane Eliete Laguila Visentainer

\begin{abstract}
In this issue of the Journal of Hematology and Hemotherapy, a study by Morais et al. evaluated four classical methodologies of lipid extraction (Folch, Bligh-Dyer, Rose-Gottlieb and Gerber) and an alternative technique, in order to evaluate the efficiency of extraction and fatty acid composition of human plasma. The alternative method proposed by the authors uses a microwave oven, and is considered efficient to extract lipids and identify fatty acids, but not for their quantification. The most suitable extraction method to measure fatty acids in human plasma is the Folch method.
\end{abstract}

Keywords: Fatty acids/blood; Lipids/analysis; Lipids/chemistry; Biochemistry/methods

In humans, omega-6 (n-6) and omega-3 (n-3) series fatty acids are important to maintain cell membranes, brain function and nerve impulse transmission. ${ }^{(1)}$

Linoleic (LA, 18:2 n-6) and alpha-linolenic (LNA, 18:3 n-3) acids are strictly essential fatty acids, which must be obtained through the diet. The other n- 6 and n-3 fatty acids can be synthesized from LA and LNA or be obtained through the diet.

Of the n-6 and n-3 series fatty acids of nutritional value, arachidonic (AA, 20:4 n-6), eicosapentaenoic (EPA, 20:5 n-3) and docosahexaenoic (DHA, 22:6 n-3) acids are the most important.

As in the human body, LA, an n-6 fatty acid, must be converted into AA, and LNA, an n-3 fatty acid, into EPA and DHA in order for them to exercise their functions, many kinetic studies are performed to measure these conversions from diets with different n- $6 / \mathrm{n}-3$ ratios. ${ }^{(1)}$

The first step in the process to assess the fatty acid composition of different foods and biological materials is to extract the lipids. Extraction methods are crucial to accurately measure fatty acid concentrations, as methods may degrade some fatty acids, especially polyunsaturated fatty acids and thus overestimate the true values.

Accordingly, in this issue of the Journal of Hematology and Hemotherapy, a study by Morais et al. ${ }^{(2)}$ evaluated four classical methods of lipid extraction (the methods of Folch, Lees and Stanley, ${ }^{(3)}$ Bligh and Dyer, ${ }^{(4)}$ Rose-Gottlieb, ${ }^{(5)}$ and Gerber $^{(6)}$ and an alternative technique, proposed by the authors, with the objective of comparing the efficiency of lipid extraction and to evaluate the fatty acid composition in total lipids from human plasma. 